\title{
Biological Damage, as a Special Figure of Non-pecuniary Damage and Problems Encountered in Albanian Jurisprudence
}

\author{
Dr. Juliana Bylykbashi \\ Prof.as. Dr. Eneida Sema Dervishi \\ Faculty of Law, \\ University of Tirana, \\ Tirana, Albania
}

\begin{abstract}
Non-pecuniary damage is one of the institutes of civil law that aims to protect and restore the rights of personality laid out in certain provisions of the Constitution of the Republic of Albania and expressly referred to in Article 8 of the European Convention on Fundamental Human Rights and Freedoms. Judicial jurisprudence has rendered non-pecuniary damage in the case of health damage, physical or psychological integrity in three separate types of damage: biological damage, moral and existential damage. The subject of this paper will be one of the figures of nonpecuniary damage, biological damage or otherwise called damage to health, being a matter of little or no treatment and the problems it faces in Albanian jurisprudence. One of the topics to be dealt with in this paper is the manner and criteria for calculating health insurance compensation, a topic that has met discussions about the actual value of the compensation or the value of the expected income that the injured party or relatives should receive from social insurance. In the provisions related to the value of the compensation coverage, insurance laws and bylaws foresee certain limitations, not only in the method of calculating non-pecuniary damages, but also with regard to the minimum amount of insurance coverage by the insurance companies. Referring to Albanian court practices there have been cases where there has been discrepancies in the calculation of biological damage between the insurance companies and the court.
\end{abstract}

Keywords: biological damage, moral damage, existential damage, temporary disability, permanent disability, social security

\section{Introduction}

Damage to health results from the violation of one's physical and / or mental integrity. Some authors regard the right to physical integrity as a right to personality, which may be attached to the principle of human dignity. ${ }^{1}$ Human rights to life and health are objective rights that arise and are inviolable and indivisible from their very existence.

\footnotetext{
${ }^{1}$ LAMBERT-FAIVRE (Y.), Droit du dommage corporel, Systèmes d'indemnisation, Précis Dalloz, 8e éd., 2015
} 


\section{Journal of International Cooperation and Development}

www.richtmann.org/journal

Vol 2, No 2, November 2019

Therefore, as such they are protected and guaranteed as fundamental human rights by the Constitution of the Republic of Albania. ${ }^{2}$ Protection of human health is expressed not only in the obligation of the government for health care (Article 15/2 and Article $59^{3}$ ), but also in the right to exercise this protection in court (Article 42/2), inter alia, by forcing anyone who violates one's physical and mental integrity to compensation for the damage caused. Among the areas of objective law that sanction the protection of human health from the unlawful acts or omissions of a third party, the Civil Code, in particular in letter a) of Article 625, stipulates that: "a person suffering damage other than property, has the right to seek compensation when ... (a) he has suffered damage to his health ..."

In this paper we intend to treat health damage as an autonomous figure of nonpecuniary damage, different from property damage "for loss and diminishing of the ability to work" ${ }^{4}$. One of the areas where non-pecuniary damage has been most prevalent and consequently the relevant compensation for this damage is that of road transport accidents. Road traffic, by any motorized vehicle, is one of the main sources of added risk ${ }^{5}$. Due to their characteristics, road traffic vehicles can cause serious material and human life and health damage. So, as a result of accidental events in the field of transport, we are faced with damages of personal and material nature. Damages of a personal nature, furthermore, are divided into property and non-pecuniary damages. Personal damages, both of property and non-pecuniary nature, are the result of damage to human life or health, as the highest values protected by the rule of law.

Presently, the main difficulties for health damage compensation relate to on the one hand to the determination of the various elements that constitute health damage and the assessment of the damages and legal interests associated with it, and on the other hand the impact of social payments made by social organizations. But the fact that indemnities compensate health damage for bodily injury it raises a number of problems regarding their legal status. The consequences of bodily injury being wounds or loss of life are numerous and difficult to discern. There are economic consequences, such as care expenses, or loss of professional profit. But often beyond damages of a financial nature, the violation of bodily integrity also includes moral damages affecting the injured and his relatives. All these economic and moral damages must be identified in order to be judged on the principle of full compensation, which constitutes a serious

\footnotetext{
${ }^{2}$ Article 3,15/1 and 21 of the Constitution of the Republic of Albania

${ }^{3}$ Chapter V "Social Objectives", Article 59 of the Constitution of the Republic of Albania defines the social objectives of a state in order to protect its citizens in the direction of ...... e) care and assistance for the disabled, and f) health rehabilitation. ,... .Integration of people with disabilities into society and improvement of their living conditions.

${ }^{4}$ Article 641 of law no.7850, dt. 29.07.1994 the Civil Code of the Republic of Albania

${ }^{5}$ Article 622 of the Civil Code and the decision no.73 dt. 16.02.2010 of the Civil College of the Supreme Court
} 
difficulty.

Further, the consequences of bodily harm are often difficult to assess. The economic damage resulting from them extends over time even after the compensation rate has been determined. As a consequence, courts in making this assessment, are often required to formulate hypotheses about the future, referring to simple probabilities, that is, to running a series of rough ${ }^{6}$ calculations for bodily harm.

Lastly, the suffering that the injured person must endure ${ }^{7}$. Compensation for the suffering of the injured known as "pretium doloris" was once associated only with physical pain. Nowadays, the post-traumatic moral suffering expressed as psychological suffering in the form of anxiety, fear, depression, etc. are added thereupon. The Resolution adopted in $1975^{8}$ by the European Council in an attempt to harmonize the various national legal systems on the victim's bodily injury compensation, for the economic loss, based on the principle of full compensation, did not create any theoretical argument regarding the topic of: Are money really able to "compensate" all losses and absences from a fair monetary evaluation? On the other hand, the principle of full compensation for health damage raises doubts about non-pecuniary damage. It is really easy to be ironic about "full compensation" for amputees, paraplegics, or traumatic brain injuries, because it seems impossible to "repair" the irreparable nonpecuniary, personal, moral, existential damage. According to a French author.... "If money does not" repair "anything, the only way to give the victim a satisfactory compensation is to first and foremost recognize his dignity as a human being, not lost from the incapacitated effects of the accident, but respected in his physical integrity, to which man gives a "value," is the recognition of his suffering, is the recognition of his person, body and soul, in his identity and individuality, useless to anyone else. "9

\section{Overall Evaluation of the Bodily Harm Determination}

Permanent loss of function resulting after post-rehabilitation condition has still ongoing

\footnotetext{
${ }^{6}$ Viney, $G$, Jourdain, $P$, Les effets de la responsabilite, Traite de droit civil, 3 edition, LGDJ lextenso editions, 2010, p. 257

7 According to the French compensation system, their assessment is made by considering traumatism as "very easy" "moderate" "moderate" "relatively" "relatively large" large "very large" but the more commonly used figure is from 1 to 7.

${ }^{8}$ The European Council: "Resolution (75) 7 on Compensation for Damage in the Case of Personal Injury and Death", adopted by the Committee of Ministers on 14 March 1975; see also Y. Lambert-Faivre, Droit du dommage corporel, 3e éd., coll. "Précis Dalloz», Paris, Dalloz, 1996, $p$. 39-57., See Lambert-Faivre, Y. (1998). Indemnification of non-economic prestige victories. Les Cahiers de droit, Volume 39, Number 2-3, p. 540,537-569. https://doi.org/10.7202/043503

9 Lambert-Faivre, Y. (1998). L'indemnisation des victimes de préjudices non économiques. Les Cahiers de droit, Volume 39, Number 2-3, p. 540, https://doi.org/10.7202/043503
} 


\section{Journal of International Cooperation and Development}

www.richtmann.org/journal

Vol 2, No 2, November 2019

consequences for the injured. This item on the damage list has been added by the European Commission and coincides with "the ultimate weakening of the physical, psycho-sensory or intellectual power found after proper clinical examination, therefore related to the disruption of daily existence." The aim is to compensate not only for the physiological functions of the injured person, but also the permanent pain he feels, the loss of quality of his /her daily life ${ }^{10}$. Therefore, there are three constituent elements of this type of damage: 1 . functional loss, 2. their actual effect on the condition and quality of life of the injured person, and 3. persistent post-traumatic pain. Whereas in the case of temporary disability, traditionally, courts refer to the notion of "temporary disability at work" which relates to the period during which the injured person cannot work because of his/her physical condition. During this period of temporary disability, there is a period of total temporary disability, during which the injured person is unable to perform his/her professional duties (medical report) and a period of partial temporary disability during which he or she gradually recovers for his/her latest work. But the concept of temporary disability for work remains unclear, as there were cases where the injured person started full-time work, although the physician considered him/her not completely recovered. The notion of temporary disability at work serves to determine the duration in days of the interruption of professional activity in the event of total disability and in the event of a gradual return to work it indicates a reduction in activity resulting therefrom.

After a clinical evaluation, the forensic medical expert determines the percentage of functional disability which is then translated into a compensation rate. The ability to work criterion is expressed as a percentage. This percentage measures the permanent impairment of the physical and mental integrity of the injured. The issue is raised in various terms for permanent functional disability and other moral damages related to physical and moral suffering.

\subsection{Indemnity Damages Indirectly}

Bodily injury affects not only the injured but also third parties, who are affected by the physical integrity of the direct injured person, e.g. employees, employer, business partner, etc. In practice, compensation of this kind are rarely awarded. It is often the relatives of the injured who suffer this type of damage. European jurisprudence has foreseen other types of non-pecuniary damage that have rarely been claimed by injured parties in Albania and rarely treated by a judge, e.g. accompanying damage, regarded as a "shock in living conditions", taking into account no only blood ties, but also the

10 Derobert, L Rapport aux journees d'etudes du cimite europeen des assurances, RGAT, 1963, p.395; see viney, $G$, jourdain, $P$, Les effets de la responsabilite, Traite de droit civil, 3 edition, LGDJ lextenso editions Viney, 2010, p. 300 


\section{Journal of International Cooperation and Development}

www.richtmann.org/journal

Vol 2, No 2, November 2019

closeness to the injured. So the psychological suffering, the feeling of loneliness after the loss of the person with whom you have had an affair, the moral damage that you suffer, all of these must be assessed in a personalized way. Loss of property can be cited as loss of income from relatives. Relatives may claim loss or reduction of income that was paid directly by the injured party but lost this right due to the disability of the injured party.

\section{Juridical Treatment on the Criteria and Compensation of Biological Damage}

Under Articles 3,15 and et seq. of the Constitution, it is foreseen a special and equal protection of man's non-pecuniary and property welfare. In this sense, Article 608 and et seq. of the Civil Code aims at establishing a complete restitution of any damage suffered illegally, i.e. not only in the strictly economic definition of property, but also in the non-pecuniary welfare representing human values. In the interpretation of Article 625 / a of the Civil Code of the Republic of Albania, impairment of health includes not only the pathological condition, but also the moral damages, that is, the spiritual suffering and the deterioration of the relationships involving the quality of their lives. The unifying decision of 2007 makes a precise determination of the juridical nature of non-pecuniary damage, namely health or biological damage based on the provisions of the Civil Code. At its core, Article 625 of the Civil Code recognizes the right to indemnification for any non-contractual non-pecuniary damage that is different from property damage. In this sense the provision of article 625 of the Civil Code distinguishes between two groups of fundamental human rights and freedoms that are of no material nature and are thereby protected in case of violation: a) damage to health (absolute right to health in the biological sense) and personality infringement (the entirety of absolute personality rights) ${ }^{11}$ Health damage, also known by jurisprudence as biological damage, is a specific figure of non-pecuniary damage and as such, it is subject to independent due compensation. Unlike property damage, biological damage has no economic value in the free market, its violation is compensated neither in kind, nor in cash. But for the sake of health protection, and physical and social rehabilitation and facilitation of the injured in the future, the person responsible for causing the biological damage is obliged to pay him/her compensation in cash, independently of other property and non-pecuniary damages that may have eventually occurred to the injured party because of the same unlawful fact. ${ }^{12}$

Unlike other non-pecuniary damages, biological damage, not having a merely pure sensory nature, is inherently objectively verifiable. The definition of damage to health or biological damage is also provided in subsequent legal acts and more specifically in Law

\footnotetext{
${ }^{11}$ Unifying Decision of the United Colleges of the Supreme Court no. $12 d t .14 .07 .2007$

${ }^{12}$ Ibid.,
} 


\section{Journal of International Cooperation and Development}

www.richtmann.org/journal

Vol 2, No 2, November 2019

no. $10076 / 2009^{13}$ and Regulation No.53 /2009 'On the treatment of damages covered by the obligatory insurance contract in the transport sector "enforced by the aforementioned law, which defines it in more detail, as: violation of human health, physical and / or mental integrity and which has a negative impact on the day-to-day life activity, in the dynamic and inter-personal aspect of the injured party's life, despite the potential return of its capacity to generate income. ${ }^{\prime 14}$ Damage under law 10076/2009 is assessed for medical expenses and other necessary expenses incurred in accordance with health insurance laws, including a proportionate pension quota for the injured party or his family members (Article 27 of the Act). ). According to the legal provisions of the Civil Code, the damages that should be compensated the injured for the damage caused by biological damage are: damage to health as a separate damage; loss / diminishing of ability to work as an economic damage; medical expenses incurred or to be incurred in treating the injured; personality trauma, change of lifestyle.

If we were to analyze biological damage in the spirit of the above legal and by legal acts, we think that there is a need for adjustments in some of its articles, regarding the rights and compensation of the injured party, which we will present as follows:

First, the injured party, based on insurance, has the right to file a claim for damages with the responsible insurance company of the owner of the vehicle that caused the accident. Article $12^{15}$ of the law also stipulates the time limits within which the responsible insurer will handle the claim for damages. The timeline is an important element for the injured party to claim damages, because in the event of non-compliance with these deadlines, the injured party has the right to bring a civil action against the responsible insurer, and secondly, the right to payable interest for each day of delay in settlement of indemnity by the responsible insurer. I think that an adjustment should be made to the law as to the date of the claim for damages for the injured party. It should start not from the date of compiling the documentation, as currently foreseen by law, but from the date of receiving a claim for damages, within the same time limit as foreseen for property damage. This time difference is not necessary. This we think should be done for two reasons: it provides necessary time for the insurance company to handle the claim for damages along with the claim file, and second, it presents itself as a "sanction" for the insurance company to handle the claim at the proper time, without delay and in defense of the injured party's interests in obtaining the right to benefit from the payable interest, making no distinction between the property damages and non-pecuniary damages.

\footnotetext{
${ }^{13}$ Article 3, point 8, of the law on compulsory insurance in the transport sector: "non-pecuniary damage is biological damage .... resulting from death, bodily injury and deterioration of health suffered by the injured party or its relatives"

${ }^{14}$ Article 29 of Regulation No. 53, dated 25.06.2009 "On the treatment of damages covered by compulsory insurance in the transport sector" amended by the Financial Supervisory Authority

${ }^{15}$ Article 12, point 2 of the law, for non-pecuniary damage within 90 days, for property damage within 30 days
} 


\section{Journal of International Cooperation and Development}

www.richtmann.org/journal

Vol 2, No 2, November 2019

Second, for the determination of the rate of health compensation, reference is made to tabular technical criteria that contain the degree of the injury, the age of the injured, the damage assessment base unit, and the relevant life-correction coefficient. The determination of these elements in the calculation of this damage seeks to personalize the treatment and evaluation of this damage on a case-by-case basis, which takes different forms in different cases and cannot be unified with a fixed value because the injured do not share the same experience in as far as the best interests of their health, their physical and / or mental integrity. The court in this case must guarantee an equal assessment of the proportion of the amount of compensation for biological damage, if the age and the type of physical or mental health damage suffered are the same. ${ }^{16}$ Complications encountered in Albanian court cases relate to the calculation of non-pecuniary damage which shows discrepancies in the calculation of non-pecuniary damage caused between insurance companies which implement normative acts and Courts which, in calculating permanent or temporary biological (health) damage, take into account a number of factors in order to make the damage compensation as complete and comprehensive as possible. Insurance companies in the calculation of non-pecuniary damage implement normative acts such as Financial Supervisory Authority Regulation No.53 / 2009 "On the Treatment of Claims Covered by Compulsory Insurance in the Transport Sector" which sets out the tabular technical criteria for the calculation of property and non-pecuniary damage based on fixed formulas, and Law $10076 / 2009$ "On compulsory insurance in the transport sector", which sets out the limits of benefit for an insurance event which limits cannot be exceeded (Art. 26). While Courts in the calculation of non-pecuniary damage still in some cases make reference to the Unifying Decision. Nonetheless these cases are becoming less as a consequence of consolidation of practices, which mostly refers to Law 10076 and Regulation No. 53.

Third, the insurance companies, in the interpretation of Regulation No. 53 and Law No. 10076, calculate the moral and existential damage as a common figure of nonpecuniary damage under Article 30 point $5^{17}$. Whereas the Courts in many cases interpret this provision differently, reasoning that these two non-pecuniary damage figures are separate and represent different damages, ${ }^{18}$ based also on the conclusions of the unifying decision. The Unifying Decision treats them completely as two different

\footnotetext{
${ }^{16}$ For more see Decision No. 5560 dt. 24.06.2009 Tirana Judicial District Court

${ }^{17}$ Article 30, point 5, stipulates that: The value of moral and existential damages for permanent partial disability shall be calculated for every $10 \%$ of the degree of disability at a rate of 100,000 $A L L$, from this value the family members of the injured person can not benefit more than $1 / 3$ of the value of the benefit

${ }^{18}$ See Decision no. 9919 dt.25.11.2009 Tirana Judicial District Court p.15, a verdict the Saranda Judicial District Court states, "In relation to non-pecuniary damage figures, the second version calculated by the expert must be accepted, where moral and existential damage are accounted for as separate figures.
} 


\section{Journal of International Cooperation and Development}

www.richtmann.org/journal

Vol 2, No 2, November 2019

figures of non-pecuniary damage.

Fourth, another problem encountered in practice relates to the individuality of compensation value. Section 30 of Regulation no. 53, which declares moral and existential harm, mentions "family members" as persons who receive compensation, not specifying whether this right belongs to each individual or all together. Such uncertainty leads to constant misinterpretation and misapplication of the spirit of the law, defining compensation often as solidarity, and denying each family his or her legitimate rights to full individual compensation. Compensation in each case must be individual for the family, for two main reasons. First, each person has his or her individuality, the pain and experiencing is different and independent of the pain of the family member. Consequently, each family beneficiary of moral and existential damage embodies its value of damage independent of other family members or the number of persons in the family. Second, if the compensation were solidarity, it would decrease for each family, the greater the number of family members. ${ }^{19}$ Consequently, in order to be in harmony with the spirit of the law, the Civil Code and European legislation in the field of insurance, it will be necessary to specify the individual nature of the right of family members to compensation, specifically Article 30 of the Regulation.

Fifth, section 30 of the Regulation does not determine the calculation of the rate of moral and existential damage in the case of damage resulting from the temporary disability to work, creating a gap in the event of temporary health damage. Most of the cases of this nature which are addressed to the Court and are not administratively resolved, relate to the fact that insurance companies in almost all cases where the injured person's disability is considered as temporary (disability which lasts up to 6 months) do not compensate for non-pecuniary damage, but only for property damage. In almost all cases, the Courts rule in favor of non-pecuniary damage be it even for 15 days $^{20}$ in all cases. Referring to the different interpretations of the Courts and Insurance Companies, the Financial Supervisory Authority (FSA) made an amendment to the regulation ${ }^{21}$ by adding another point in Article 30, which mandates non-pecuniary

19 Bylykbashi, J A Unifying decision or normative acts to calculate non-pecuniary damage? "International Conference on Recent Interdisciplinary Studies in Humanities"Sapienza University Rome, Italy, October 26-27, 2018, p.10

${ }^{20}$ Law No. 7703, dated 11.05.1993 "On Social Security in the Republic of Albania", Article 23: "The period of benefit for temporary disability starts on the 15th day of the medical report and shall last no more than 6 months from the date of payment method"

${ }^{21}$ FSA Decision no. 91, dt. 31.05.2019, "On some amendments to Regulation no. 53, dt. 25.06.2009 "on the treatment of damages covered by compulsory insurance in the transport sector", as amended, the three reasons that led to the revision of the coefficients under the Financial Supervisory Authority were: First, the average life expectancy has increased; Second, the key interest rate of $4.5 \%$ cannot be kept constant as it should reflect the country's economic developments; Third, the coefficients hitherto referred to common tables, and were not divided into women / men. Statistics have shown that the average life expectancy of women is always higher than that of men, the official AFSA data source. 


\section{Journal of International Cooperation and Development}

www.richtmann.org/journal

Vol 2, No 2, November 2019

damage compensation even for temporary disability, a change applicable to all insurance events occurring after 01.07.2018. ${ }^{22}$

Sixth, insurance companies in almost of all the cases resulting in victim's death, award the minimum rate on the basis of the calculations since the calculation of nonpecuniary damage has a minimum and maximum limit. While the courts almost always award maximum rate on the basis of the psychological expertise act which evidences the degree of the unfortunate victim and its impact on daily life of the heirs of the deceased (plaintiff in trial).

If we were to analyze the provisions of the Civil Code regarding compensation for non-pecuniary damage, damage to health, we would conclude that the injured party seeking compensation under Article 641 of the Civil Code ${ }^{23}$, after having demonstrated the damage to health, its temporary or permanent nature and the degree of the damage, has also the burden of proof to prove the value of his unrealizable income from the loss or impairment of his ability to work. At the same time, the injured party has the burden of proof to establish the value and the causal link between the damage to health and the need for care and treatment, as well as the value of the related expenses. To reach its conclusions, the court seeks the professional opinion of experts in their respective fields. Pursuant to Article 224 / a) of the Code of Civil Procedure, the purpose of the examination arises from the need of the court to ascertain or clarify the facts which require special knowledge in the relevant field. ${ }^{24}$ It is true that the Code of Civil Procedure in its Articles 224 / a, and subsequent treats of the mastery of specific knowledge in the relevant field, but it should be noted that such knowledge must be examined (verified) by a statutory authority, which in our case is the FSA, otherwise it would fail to appoint an expert with special knowledge. Therefore no person will, regardless of his/her mastery of special knowledge, be entitled in the capacity of the expert if he is not licensed. They should not only be equipped with the relevant license, but must also possess specific knowledge in the relevant field, without interfering with other areas for which they do not hold a special license and knowledge. ${ }^{25}$ The expert's

\footnotetext{
${ }^{22}$ Points 9 and 10 of the FSA Regulation as amended: Moral and existential damage from other injuries is considered damage resulting from the temporary loss of ability to work. Temporary loss of ability to work is determined for a period of up to 6 months. The amount of moral and existential damage that the injured person benefits under point 9 of this article is calculated in proportion to the period of loss of ability to work (effective July 1, 2018)

${ }^{23}$ A person who has caused damage to another's health is obliged to compensate the damage, taking into account the loss or diminishing of ability of the injured person to work, the expenses incurred for his or her medical treatment, and other expenses thereof caused by the damage.

${ }^{24}$ The role of the expert physician is to objectify and quantify the continuation and determine its attribution to the accident; it is a function of the bodily injury report, limited to its medical evaluation., for more see, Rapport sur L'indemnisation du Dommage Corporel, juin 2003

${ }^{25}$ Decision No. 93 dt. 21.09.2017 Civil College of the Supreme Court
} 


\section{Journal of International Cooperation and Development}

www.richtmann.org/journal

Vol 2, No 2, November 2019

function should be clearly separated from the legal function of damages regulation: the forensic medical evaluation should not be confused with the judge's compensatory assessment. If the determination of the exact amount of the expenditures for care and medical treatment turns out to be impossible or high, the court shall decide in its own conviction, in line with the circumstances of the case. The principle of complete indemnity urges judges to arrange for indemnity in particular situations that could not be run by the most mathematical and rigorous formula. For example, a verdict of the Supreme Court of Paris (Judgment of 6 July 1983) ruled that for the compensation of health damage suffered by a person with a disability, it was more appropriate to abandon the classic proportional compensation formula by the percentage of disability and to replace it with a completely different method ${ }^{26}$. It is clear that without the principle of full compensation "such an adaptation, which is more than humane and socially fulfilled, would not have been reached by a judge.

\subsection{Expenditure for care}

One of the elements of biological damage is the expenditure for care. An injured person to continue to lead a normal life needs assistance from a third person. The injured party has the right to seek compensation for this person's payment. Social Security law ${ }^{27}$ stipulates that when the recipient of a disability pension becomes physically (including blindness) or mentally disabled and needs the continued care of another person, he or she is given an additional 15 percent of the net assessed base. The Medical Commission on Work Ability Determination (KMCAP) determines the need for continuing care of another person ${ }^{28}$. This person also receives supplemental child support income ${ }^{29}$ for children up to the age of 18 , or when they are attending school or unable to work up to the age of 25.

The challenge encountered in the Albanian court practice is the fact that due to accidents resulting in permanent health status as a first-degree invalid, in addition to constant mental pain, deterioration of living conditions, disability to perform any work and inability to live a normal life, the insurance companies do not award him/her daily care compensation that should be provided indefinitely and permanently to other

\footnotetext{
${ }^{26}$ The court has affirmed that.... "The special situation of a person with a disability requires specific compensation for the post-trial period." It is necessary to replace the usual compensation system with a method tailored to the real future needs of the disabled person, in order to provide the survival conditions as satisfactory as possible, taking into account the environment in which they live"

27 In section 38, supplementary care income

${ }^{28}$ Article 80 under Social Security Law

${ }^{29}$ Article 39 under Social Security Law
} 


\section{Journal of International Cooperation and Development}

www.richtmann.org/journal

Vol 2, No 2, November 2019

specialized persons or their family members. There have been litigation cases where the injured party, as a result of the accident, sustained serious health injuries that rendered him/her unfit to fulfill his personal needs. Tirana Judicial District Court ${ }^{30}$ decides to dismiss the lawsuit without recognizing these expenditures. ${ }^{31}$ The Court of Appeal, ${ }^{32}$ too, dismisses the claim regarding the expenditures for care as unfounded in evidence and law. This is due to the fact that the plaintiff did not attach any evidence in the court file to prove that she was cared for by a sanitary worker during the 5 years and moreover that the sanitary worker was paid by the plaintiff. In this regard, the only Legal Body or Institution that determines whether a guardian is needed is KMCAP, and as long as there is no document in the court file to prove that KMCAP has determined the need for a guardian for the injured party, then, in these circumstances, the Court of the Tirana Appeal Court finds that this claim should be dismissed. ${ }^{33}$ "So, although the Court did not recognize the expenditures for care in the said case, it does not mean that they cannot be part of the claim for non-pecuniary damage. The injured party, as mentioned ut supra, has the burden of proof to establish the causal link between health damage and the need for care and treatment, as well as the value of the relevant care expenses, and to claim this expense in the subject-matter of the lawsuit because the court that judges the dispute renders the verdict only on the object of the claim. ${ }^{34}$

\subsection{The base salary on which the indemnity will be calculated}

Another challenging aspect of calculating the compensation due to the injured party in an automobile accident involves cases where the injured party has not been employed: which wage will be used in compensation calculation the minimum or average wage? Of course, the insurance companies, which are responsible for awarding such indemnities, claim to use the minimum wage, basing their approach on the Regulation. On the contrary, the injured party claims the calculation be made on the basis of average salary, a claim which is based on the Civil Code. One of the reasons given by the insurance company for their approach is connected with the introduction of law no. 10076/2009 whereby the problems related to the treatment of damages were channeled into specific rules, and consequently, pursuant to this law, a Regulation was adopted, on the basis of which damages will be calculated. The injured party contends that this section of the Regulation is in breach of the Civil Code, and since the latter has the highest legal

\footnotetext{
${ }^{30}$ Decision No. 11126, dt.18.11.2014

${ }^{31}$ See Decision of the Tirana Judicial District no. 11126, dt. 18.11.2014

${ }^{32}$ Decision No.240, dt. 02.02.2016

${ }^{33}$ Decision of Tirana Court of Appeal no. 240, dt. 02.02.2016

${ }^{34}$ Article 6 of the Code of Civil Procedure, which explicitly states: "The court adjudicating the dispute shall express it self on all that is required and only on what is required"
} 


\section{Journal of International Cooperation and Development}

www.richtmann.org/journal

Vol 2, No 2, November 2019

force, that section of the Regulation should not apply ${ }^{35}$. According to Article $646^{36}$, the rate of the compensation is calculated on the basis of the salary received by an employee with the same qualifications and work experience as the injured party. So in determining the biological or existential damages, the court must award such an amount to match the potential benefits ${ }^{37}$ that the injured party would receive if he were employed and to the maximum exercise of his professional capacity, including a) years of work experience, b) different types of work the injured party could do at the time of the injury c) education d) personal qualifications, e) the actual opportunities of the injured party for employment and receiving a salary of a certain level. In the event that the injured party was in legal business at the time of the caused damage and received a higher salary than the salaries used to calculate the social security benefits, the compensation shall be awarded in reference to the actual salary earned by the injured party and not in reference to the benefit he / she receives (or would benefit) through the social security mechanism. We need also pay heed to the time reference the minimum wage is calculated: The time reference should be made from the day of the liquidation of the claim and not from the day of the accident. ${ }^{38}$

\subsection{Assessment of damage to minors}

Another difficulty related to the calculation of the said damage is the legal basis i.e. the Civil Code or the Regulation to be implemented in case of a car accident causing loss of life of a minor. Articles 646 and $647^{39}$ of the Civil Code do not limit the rate of this damage to a fixed rate of ALL 1,000,000 in cases where the victim of the accident was a minor, as provided in Article $14{ }^{40}$, point "e" of "Regulation" no. .53 / 2009 of the

\footnotetext{
${ }^{35}$ This position is also taken by the Tirana Judicial District, by decision No.4676, dt. 01.06.2016.

${ }^{36}$ Quote: "For a person who has not been employed or not insured, the amount of compensation for damage resulting from death or damage to health shall be determined by the court on the basis of the salary an employee of that category receives, which can be equal to the work that the injured party did or could do"

37 Skrame, O, Komentar i Kodit Civil i Republikës së Shqipërisë, Vëllimi i dytë, shtëpia botuese Onufri, p.150

${ }^{38}$ Mataj, R, Trainim i Shkollës së Magjistraturës, 05.02.2019, p.20

${ }^{39}$ Article 647 states that: "The injured minor, when he reaches the age of sixteen and has no pay from his employment, is entitled to swap his living remuneration with the compensation for the loss of his ability to earn, at the rate of the average salary of an employee according to the criteria of article 646 of this Code. At the age of eighteen, he is entitled, instead of the remuneration he receives, to claim the average salary, the worker of that category would have earned or should have earned had his health not been harmed."

${ }^{40}$ Article 14 of the Regulation states that: "when the deceased is under the age of 16, his/her heirs shall be reimbursed a fixed sum of 1,000,000 ALL"
} 


\section{Journal of International Cooperation and Development}

www.richtmann.org/journal

Vol 2, No 2, November 2019

Albanian Financial Supervisory Authority (AFSA). Part of the jurisprudence ${ }^{41}$ takes the view that the provision made in this article of the Regulation is in breach of the legal criteria laid down in the provisions of the Civil Code, which do not limit the calculation of the claim to the minimum wage or the obligation to have a confirmed income and, to a lesser extent, does not provide for fixed rates set "a priori" without any legal cause. This group claims that the provision of fixed compensation rates in AFSA Regulation 53/2009 violates the principle of equality, as provided by Article 18 of the Constitution, where the injured are discriminated and treated differently because of their age, social, educational and health background. The rest of the authors are of the opinion that the AFSA Regulation No.53 / 2009, as a by-legal act issued pursuant to Law no. 10076/2009 "On compulsory insurance in the transport sector" is the only act that stipulates the methodology and tabular criteria for calculating the rate of indemnity; while the law defines only the limits of damage coverage and is silent of the criteria definition. To this amount are added only the burial expenses at a fixed rate of ALL $250,000^{42}$, which is also stipulated under article 15 of the Regulation. With regard to this amount, we think that it does not show the true rates of compensation, because the law was published 10 years ago and it needs revision to reflect the economic, social and social changes of the time.

\section{Variability of the Award of Damages}

Compensation for property damage at first glance seems to be unchangeable, as the injured person is compensated for the loss of his property objectively at the moment of damage ${ }^{43}$. However, in the case of health damage, under Article 642 of the Civil Code, it is recognized as a variable and non-fixed compensation depending on the future improvement or deterioration of the health, increase or decrease of the working capacity of the injured party. Biological damage under section 642 may be amended at a later moment in time, even after a court decision ${ }^{44}$ has awarded compensation. These include: 1. Compensation for damage to health as a separate injury; 2 . Compensation for the reduction of the ability to work as economic damage. Therefore, with an actual change of conditions, the debtor and / or creditor is entitled to turn to the court to seek a change in the compensation rates. The conditions which justify the commission of such an action are thoroughly determined by Article 642; they are: a) improvement / aggravation of creditor's health after a prior ruling on the determination of the liability

\footnotetext{
${ }^{41}$ Decision No. 5870, dt. 04.07.2016, of the Tirana Judicial District

${ }^{42}$ Article 15, point "e" of AFSA Regulation No. 53/2009

${ }^{43}$ MATAJ, R Përgjegjësia Jashtëkontraktore e organeve publike në Shqipëri, PhD thesis, Tirana, 2017

44 SKRAME, O Komentar i Kodit Civil i Republikës së Shqipërisë, Vëllimi i dytë, shtëpia botuese Onufri, p.150
} 


\section{Journal of International Cooperation and Development}

www.richtmann.org/journal

Vol 2, No 2, November 2019

for damages and the relevant compensation rate thereof ; b) increase / decrease of the creditor's ability to work as a result of the damage caused by the debtor; and c) the change in the salary received by the creditor who is a party to a legal employment relationship, when the change is due to damage caused by the debtor. The question that arises regarding this provision is; Can the insured person appear in court again to claim medical expenses, for example he has lost his leg in an accident and as his age progressed, a prosthesis should be replaced? There are authors who think that although Article 642 mentions only two types of damage compensation, a third liability should be added, namely "compensation for the expenses incurred or to be made for the medical treatment of the injured party ${ }^{45}$. It may be that the condition of the injured person was initially thought differently and consequently the medications to be taken were prescribed to a certain value. But later it turns out that the initial diagnosis was not entirely accurate and as a consequence the creditor (or his family in accordance with the jurisprudence of the court) has the right to turn to the court seeking to change (increase) the amount to be paid by the debtor (the cause of the damage). The inverse of this question would be: if a person declared by a court decision to be permanently incapable of work and has received $X$ compensation, improves his health and becomes fit for work, is the insurer entitled to claim prosperity without cause to receive back part of the indemnity paid? This question leaves room for further considerations.

\section{Social Security Constituting a Part of the Injured Party Compensation}

The existence of social benefits paid to the injured or relatives by social security raises the question of whether these benefits are added to the amount of compensation that the offender or the insurance company is obliged to pay? Article 645 of the Civil Code states: "When a person receiving social security benefits dies or suffers damage to health, the damage shall be compensated in the manner prescribed by law." Whereas the law on compulsory insurance in the transport sector $10076 / 2009^{46}$, stipulates that.... "The insurance company is liable to compensate the damages of the institutions that cover health, pension, disability insurance within the liability limits of the insured and within the limits stated in the insurance contract ". Points 2 and 3 of Article 27 are disputable"...... including also a proportionate amount of the pension of the injured party or members of his family. This proportionate pension amount shall be determined in accordance with the Law on Social Security, as the difference between the disability pension determined by the decision of the social security institute and the disability pension determined in the event of an accident at work "This provision shall apply mutatis mutandis to damage compensations paid by voluntary health, pension, life, or

\footnotetext{
45 Ibid.,

${ }^{46}$ Article 27, "Application for reimbursement of Social Security Holder"
} 


\section{Journal of International Cooperation and Development}

www.richtmann.org/journal

Vol 2, No 2, November 2019

other similar insurance. ${ }^{47}$

The above provisions leave room for interpretations regarding the health damage compensation. We face completely different legal relations. What is the distinction and the compensation rate between the disability pension determined by the decision of the social security institute and the disability pension in the event of an accident at work? Depending on the conditions of the disease we have several types of concepts about disability, dividing them into physical disabilities, which are related to physical injuries that result in the malfunction of any body organ and physical disability, as a result of a professional injury, as a result of the work performed by the person ${ }^{48}$. Subjects suffering from an accident at work ${ }^{49}$ or occupational disease ${ }^{50}$ will be considered those who originate from the type of work and the workplace. Categorizing the degree of disability from occupational accident and occupational diseases is the same as categorizing disability as a consequence of general illness. The distinction lies in the years of insurance term (although they may have not completed per the law, this subject will benefit from this branch of insurance) which is the main reason why persons who may become disabled as a result of an occupational accident / occupational diseases do not fall under the disability group with various illnesses, not work related, and secondly, because of the amount of benefits, where the subject receives more income and types of benefits such as: additional medical care and rehabilitation, disability care, compensation for reasonable material damage and death allowance. ${ }^{51}$ On the one hand there is the mandatory relationship based on social security law ${ }^{52}$ and on the other the legal relations based on a compulsory insurance contract governed by law 10076/2009 "On compulsory insurance in the transport sector", a special kind of insurance contract (for the benefit of the third party). If we were to add a third legal relation dealing with the legal provisions of the Civil Code governing the voluntary insurance contract, for the insurance of property or insurance of a person ${ }^{53}$ Article 1161, the Civil Code stipulates: "The insurance sums deriving from the person's insurance contracts are paid regardless

\footnotetext{
${ }^{47}$ Article 27, point 4 of the law

${ }^{48}$ Peto, ZH, "E drejta e mbrojtjes shoqërore" Adelprint Publishing House, Tirana 2011, p. 329

${ }^{49}$ Accident at work shall be considered any type of accident that a person suffers within the premises of the undertaking, during work, during break hours, as well as on the way home from work or vice versa, based on DCM no. 788, dt. 14.12.2005 "On the determination of accident at work or because of work";

${ }^{50}$ DCM no. 396, dt. 28.06.2007 "On the determination of occupational diseases";

${ }^{51}$ Article 43, Types of Benefits, Chapter IV, Payments for Occupational Accident and Occupational Disease Insurance, Law No. 7703, dt.11.05.1993 "On Social Security in the Republic of Albania"

52 Law No. 7703, dt. 11.05.1993 "On Social Security in the Republic of Albania" is based on the contributory system upon gross wage earnings.

${ }^{53}$ Chapter XXIII, Title II, Part V of the Civil Code (Articles 1113-1149) states the provisions governing the voluntary insurance contract
} 


\section{Journal of International Cooperation and Development}

www.richtmann.org/journal

Vol 2, No 2, November 2019

of the sums that may be paid by social security."

If we were to analyze the legal provisions above, we would conclude that the benefits provided by the social and health insurance system are based on contributions paid as a result of work remuneration and not compensation related to health damage. We are in front of two completely different moments.

Disability pension is a pension that is earned by the injured person, from the social security system and as such is part of the total amount of the benefits he or she receives from such social insurance. In some cases, Albanian courts apply an overlap between the legal provisions of the Civil Code governing the voluntary insurance contract, and the legal provisions governing compulsory third party liability insurance. The court ruled in a judgment that: ..... "The amount of compensation for health damage by the Compensation Fund shall not exceed the value of the proceeds that the injured party may benefit from social security. This is a matter that the law has resolved, and what is expected by the Relevant District court is the rigorous application of the criteria and methodology set out in the by-laws, in the assessment degree of the damage to health and the ratio of this amount with the expected income that the plaintiff may benefit from social security due to the disability caused by this injury.

We believe that the proportionate rate that the legislator has set is not fair, as it violates the rights of the injured to full health damage compensation. They must be calculated on the basis of the person's contributions to the social security system, the premium paid under the compulsory insurance contract, and the premium paid under the voluntary insurance contract, for a comprehensive indemnity based on the law and the contracts signed between the parties. The legislator favors the prevalence of the principle of compensation entitlement that consists in calculating the (total) liability then subtracting the social benefits that the injured party or his / her relatives receive from "third party payers". We exclude cases where there are more than one injured persons, direct or indirect, wherein the deduction of payments made to each third party cannot be entirely deducted from the value the third party has to pay, but must be calculated on the share of the compensation corresponding to each damage.

\section{Conclusions}

The juridical treatment of biological damage, as set out above, raises some concerns regarding non-pecuniary damage and in particular health damage, whereby we can conclude that the compensation paid to the injured by the insurance companies does not correspond to the real costs the injured person incurs to survive and live a normal life.

Not only this argument, but also in view of the main purpose of the compensation i.e. returning the injured to his/her original conditions as if the harmful act had not occurred, the legal acts in this area have imposed restrictions on the extent of the 
compensation for the injured and / or his relatives. We are dealing with a marked deterioration of the condition of citizens regarding their right to compensation as a result of the non-pecuniary damage they may suffer from a road accident.

The state, in its responsibility to guarantee the exercise of the individual's personality rights, and its obligation to provide the appropriate conditions implement them, must find the proper mechanisms to protect and guarantee the fulfillment of the individual's rights.

We think it is time to revise some provisions of the law "On compulsory Insurance" and the regulation thereof, because they violate the compensation rights of the injured.

The court must be careful in rendering the final verdict on biological damage. Each case handled by the court is unique and the fixed formulas set out in regulations or other normative acts cannot go beyond the scope of Article 625 of the Civil Code and the unifying decision of the United colleges of Supreme Court, where the main purpose is the return of the victim to as soon as possible to the situation that he/she was prior to the offense. Also it is incorrect to claim that a sum of money can reimburse the injured for their spiritual suffering. These damages are immeasurable. However, the court, with the help of an expert, should quantify the pain and then translate it into monetary value using uniform charts based on objective criteria.

\section{References}

Viney G, Jourdain $P,(1989)$ Les effets de la responsabilite, Traite de droit civile, L.G.D.J., Lextenso editions, pg.4 Lambert-Faivre (Y.), Droit du dommage corporel, Systèmes d'indemnisation, Précis Dalloz, 8e éd., 2015

Lambert-Faivre, Y. (1998). L'indemnisation des victimes de préjudices non économiques. Les Cahiers de droit, Volume 39, Number 2-3,

Derobert, L Rapport aux journees d'etudes du cimite europeen des assurances, RGAT,1963, P.395;

Skrame,O Komentar i Kodit Civil i Republikës së Shqipërisë,Vëllimi i dytë, shtëpia botuese Onufri. Mataj, R Përgjegjësia Jashtëkontraktore e organeve publike në Shqipëri, punim doktorature, 2017 Peto, ZH, "E drejta e mbrojtjes shoqërore", Shtepia botuese Adelprint, 2011, Bylykbashi, J A Unifying decision or normative acts to calculate non-pecuniary damage?"International Conference on Recent Interdisciplinary Studies in Humanities"Sapienza University Rome, Italy, October 26-27, 2018

Constitution of Republic of Albania, modified by laë no. 9675, dt. 13.1.2007,

Civil Code of Republic of Albania approved by laë no. 7850 dt. 29.07.1994, Civil Procedure Code of Republic of Albania approved by law no.8116, dt. 29.3.1996, Law No. $10076 / 2009$, For compulsory insurance in the transport sector. Law No.7703, dt. 11.5.1993 For social insurances in Republic of Albania. Law No. 52|2014 for the insurance and re-insurance activity. 


\section{Journal of International Cooperation and Development}

www.richtmann.org/journal

Vol 2, No 2, November 2019

Rule No. 53/2009; For treating damages covered by the compulsory insurance contract in the transport contract.

Decision FSA no 91, dt. 31.05.2019

VKM nr. 396, dt. 28.06.2007 "Për përcaktimin e sëmundjeve profesionale

VKM nr. 788, dt. 14.12.2005 "Për përcaktimin e aksidentit në punë ose për shkak të punës “

Rapport Sur L'indemnisation Du Dommage Corporel, juin 2003

Mataj, R, Trajnim i shkollës së Magjistraturës, 05.02.2019,

Decision no. 12 dt. 14.09.2007 of United Colleges of the Supreme Court.

Decision no. 415/10 dt. 18.09.2013, Primary Court of Prishtine - branch of Podujeve

Decision no.199/11 dt. 04.12.2014, Primary Court Prishtine

Decision no. 5560 dt. 24.06.2009 of the Tirana District Court

Decision no. 93 dt. 21.09.2017 of the Civil College of the Supreme Court

Decision no. 11126 dt. 18.11.2014 of the Tirana District Court

Decision no. 13 dt. 22.06.2016 of the Fier District Court

Decision no. $240 \mathrm{dt}$. 02.02.2016 Tirana Court of Appeal

Decision no. $5870 \mathrm{dt}$ 04.07.2016 of the Tirana District Court

Decision no. $108 \mathrm{dt}$. 12.02.2013 of the Civil College of the Supreme Court

Decision no. 505 dt. 09.10.2014 of the Civil College of the Supreme Court

Decision no. 9919 dt.25.11.2009 Tirana Judicial District Court 